\title{
Cell-Based Therapies for Peripheral Arterial Disease
}

\section{Yasuyuki Fujita and Atsuhiko Kawamoto*}

Division of Vascular Regeneration, Unit of Regenerative Medicine, Institute of Biomedical Research and Innovation, Kobe, Japan

\begin{abstract}
Chronic critical limb ischemia (CLI) is defined as the end-stage of lower limb ischemia due to atherosclerotic peripheral arterial disease (PAD) or vasculitis including thromboangitis obliterance (Buerger's disease). CLI patients are at very high risk of amputation and experience poor physical function, leading to severe morbidity and mortality despite the development of surgical bypass technique or endovascular approach. Therefore, exploring novel strategies for blood flow recovery of ischemic limbs is urgently needed for patients with CLI. Although researchers initially focused on gene therapy using proangiogenic growth factors, recent discovery of somatic stem/progenitor cells including bone marrow (BM)-derived endothelial progenitor cells (EPCs) and mesenchymal stem cells (MSCs) has drastically developed the field of therapeutic angiogenesis for CLI. In 2002, the first clinical trial of intramuscular injection of BM-derived mononuclear cells (BM-MNCs) demonstrated safety, feasibility and efficacy for CLI patients. Since then, at least 50 clinical trials of BM- and peripheral blood (PB)-derived MNC therapy, 4 trials of CD34+ cell (an EPC-enriched fraction) therapy and 8 trials of MSC therapy have been performed for CLI. Overall, the results of these early phase clinical trials regarding stem/progenitor cell therapies may be safe, feasible and effective. However, only few late-phase clinical trials have been conducted. Currently, at least 3 phase III trials including 2 trials using BMMNCs and 1 trial using granulocyte-colony stimulating factor (G-CSF)-mobilized PB-MNCs are ongoing. This review provides an overview of the preclinical and clinical reports to demonstrate the usefulness and the current limitations of the cell-based therapies.
\end{abstract}

Keywords: Angiogenesis; Cell therapy; Critical limb ischemia; Neovascularization; Peripheral artery disease

\section{Introduction}

Peripheral arterial disease (PAD) is commonly referred to ischemia of extremities secondary to atherosclerotic occlusion. More than 25 million patients suffer from PAD in the developed countries [1-5]. An additional cause of PAD is vasculitis including thromboangitis obliterance (TAO) (Buerger's disease), which can also lead to severe limb ischemia. Chronic critical limb ischemia (CLI) is defined as the end-stage of lower limb ischemia. The clinical manifestations consist of rest pain and/or skin ulceration or gangrene. The annual incidence of CLI is estimated to be 500-1,000 cases per million people and an estimated 250,000 major amputation are performed annually in the United States and Europe, resulting in a significant socioeconomic burden and severe reduction in quality of life [5]. Prognosis of the CLI patients is quite poor. The 1-year mortality and major amputation rate are reported to be $25 \%$ and $30 \%$, respectively [5]. Currently, revascularization of the ischemic limb with surgical bypass techniques or endovascular approaches is believed to be the best option for limb salvage. However, $25-40 \%$ of patients with CLI are not candidates for either of these options due to a lack of autologous vein graft, extensive lesions in the tibial and peroneal arteries or medical co-morbidity [5-7]. Therefore, new strategies for blood flow recovery are urgently required for such no-option patients with CLI. The challenge to improve blood flow to CLI has provoked extensive research programs and numerous innovative approaches in the fields of molecular biology and pharmacology.

In early studies of vascular regeneration, angiogenic recombinant proteins including vascular endothelial growth factor (VEGF), fibroblast growth factor (FGF), hepatocyte growth factor (HGF) and cell-mobilizing cytokines such as granulocyte colony stimulating factor (G-CSF) and granulocyte-macrophage colony-stimulating factor (GMCSF) have been tested to promote neovascular formation. Although preclinical and early-phase clinical results were promising in shorttime [8-11], protein therapy did not achieve a long-term clinical effect
[12]. Subsequently, gene therapy was proposed as a therapeutic option for cardiovascular diseases. Gene therapies using naked/plasmidencoding angiogenic factors were developed to improve duration of transgene expression over direct recombinant protein injection.

Isner et al. demonstrated the effect of intramuscular gene therapy with naked plasmid DNA encoding VEGF for ischemia reduction in animal models of hindlimb ischemia [13] and confirmed the effect of VEGF165 plasmid DNA in patients with limb ischemia for the first time in $1996[14,15]$. Adenovirus-mediated VEGF121 gene therapy has also been reported to be effective in improving endothelial function and lower-extremity flow reserve in patients with PAD [16]. Thus, VEGF gene therapy appears to be promising, however, its efficacy and safety remains to be controversial because 2 phase II randomized clinical trials failed to meet the primary endpoint of significant amputation reduction [17] or improvement of peak walking time at 12 weeks, while an adverse event, peripheral edema relating to AdVEGF121 was observed [18]. Recently, Muona et al. reported a 10-year safety followup in patients receiving local VEGF gene transfer to ischemic lower limbs [19]. This study demonstrated that there were no differences in the causes of death or in the incidence of cancer, diabetes or diabetic retinopathy between the patients receiving VEGF-mediated gene therapy and the control patients. However, there were no differences in the number of amputations between the 2 groups.

*Corresponding author: Atsuhiko Kawamoto, M.D., Ph.D., Division of Vascular Regeneration, Unit of Regenerative Medicine, Institute of Biomedical Research and Innovation, 2-2 Minatojima-Minamimachi, Chuo-Ku, Kobe 650-0047, Japan, Tel: +81-78-304-5772; Fax: +81-78-304-5263; E-mail: kawamoto@fbri.org

Received July 23, 2014; Accepted September 15, 2014; Published September 17,2014

Citation: Fujita Y, Kawamoto A (2014) Cell-Based Therapies for Peripheral Arterial Disease. J Stem Cell Res Ther 4: 234. doi:10.4172/2157-7633.1000234

Copyright: (c) 2014 Fujita Y, et al. This is an open-access article distributed under the terms of the Creative Commons Attribution License, which permits unrestricted use, distribution, and reproduction in any medium, provided the original author and source are credited. 
HGF is another angiogenic factor, which regulates proliferation and migration of vascular endothelial cells through tyrosine phosphorylation of its specific receptor, c-Met. In preclinical studies, gene transfer using naked plasmid DNA encoding HGF induced therapeutic angiogenesis in animal models [20-24]. The first pilot (phase I/IIa) study of intramuscular injection of naked human HGF plasmid in patients with atherosclerotic PAD or TAO provided early evidence of safety and feasibility. Powel et al. performed another phase I/II double-blind placebo-controlled study with HGF plasmid for CLI (HGF-STAT trial) [25]. Transcutaneous oxygen pressure $\left(\mathrm{TcPO}_{2}\right)$ significantly increased at 6 months in the high-dose group $(4.0 \mathrm{mg}$ at days 0,14 and 28) compared with the placebo, low-dose $(0.4 \mathrm{mg}$ at days 0,14 and 28), and middle-dose (4 $\mathrm{mg}$ at days 0 and 28) groups. However, there were no differences in ankle-brachial pressure index (ABPI), toe-brachial pressure index (TBPI), pain relief, wound healing and major amputation between the groups. In a randomized, doubleblind, placebo-controlled clinical trial of HGF plasmid in patients with CLI, the primary endpoints including rest pain and ulcer size significantly decreased in the HGF treated group compared with the placebo group [26].

FGF is also an angiogenic factor, which has been studied in cardiovascular diseases. FGF is composed of 23 members, FGF-1 through FGF-23. In particular, FGF-1 (acidic or aFGF), FGF-2 (basic or bFGF) and FGF-4 are highly potent endothelial mitogens [27]. Among them, FGF-1 and FGF-2 have been extensively examined. Comerota et al. first demonstrated the safety and efficacy of increasing single and repeated doses of intramuscular naked plasmid DNA encoding FGF type 1 (NV1FGF) administered to patients with unreconstructable end-stage PAD in an open-label phase I trial [28]. In this study, a significant reduction in pain and ulcer size was observed after FGF-1 gene administration associated with an increased $\mathrm{TcPO}_{2}$ and $\mathrm{ABPI}$ as compared with baseline pretreatment values. Furthermore, the phase II TALISMAN trial demonstrated that administration of NV1FGF significantly reduced the risk of all amputations and major amputations at 12 months as compared with placebo, although improvement of ulcer healing was similar between the NV1FGF-treated group and the control group [29]. However, the phase III TAMARIS trial including 525 patients with CLI demonstrated no beneficial effects on either the primary endpoint of time to major amputation or death at 1 year or secondary endpoints including major amputation and death from any cause [30]. Clinical usefulness of FGF gene therapy has been controversial so far.

While outcomes of angiogenic molecular therapy trials remain controversial, accumulating knowledge of the potential of stem/ progenitor cells as therapeutic agents in both animal studies and clinical trials has shifted the interest in regenerative medicine from molecular to cell-based approaches.

In this review, we provide an overview of the basic characteristics and clinical trials of cell-based therapies for PAD and discuss regarding the current problems and the future perspectives.

\section{Cell-Based Therapies for PAD}

Transplantation of stem or progenitor cells is an attractive approach for therapeutic neovascularization. Stem/progenitor cells possess the capability of self-renewal and differentiation into organ-specific cell types as well as paracrine effects via the release of pro-angiogenic growth factors. Some of the stem/progenitor cells including bone marrow (BM)-mononuclear cells (MNCs), granulocyte colony stimulation factor (G-CSF)-mobilized peripheral blood (PB)-
MNCs, unmobilized PB-MNCs, endothelial progenitor cells (EPCs), mesenchymal stem cells (MSCs) are under investigation.

\section{EPCs and crude MNCs}

In 1997, EPCs were first identified in adult human PB as CD34 antigen-positive (CD34+) MNCs [31]. They are phenotypically characterized by expression of antigens associated with haematopoietic stem cells (HSCs) including CD133, CD34, c-kit, VEGFR-2, CD144 (vascular endothelial (VE)-cadherin) and Sca-1. The discovery of circulating EPCs changed the traditional paradigm that 'vasculogenesis' occurs exclusively in the developing embryo. EPC levels in the PB are low under normal conditions; however EPCs residing in the BM are mobilized into $\mathrm{PB}$ in response to physiological and pathological stimuli, such as myocardial and peripheral ischemia [32,33]. Mobilized EPCs recruit to the foci of neovascularization where they form structural components of the growing vasculature [34]. Accumulated recent insights into the mechanism of EPC-mediated neovascularization reveal that EPCs secrete paracrine factors including VEGF-A, VEGF-B, stromal cell-derived factor-1 (SDF-1) and insulin-like growth factor-1 (IGF-1) [35]. The paracrine effect of EPCs inhibits cell death, enhances cell proliferation, activates resident stem/progenitor cells in the ischemic tissue, and recruits additional stem/progenitor cells to the ischemic site [36-40]. On the other hand, Gehling et al. reported that a cell population positive for AC133 (CD133), a more immature HSC marker, consists of progenitor and stem cells with not only hematopoietic potential but also the capacity of endothelial differentiation [41]. Accumulated studies revealed that PB-, BM- and umbilical cord blood-derived CD34+ or CD133+ cells are enriched for endothelial lineage, can express endothelial markers and form endothelial structure in vitro and in vivo [42-45].

The discovery of EPCs guided to the development of stem/progenitor cell-based strategies for ischemic cardiovascular diseases. Since then, BM- or PB-MNCs including EPCs as well as the EPC-enriched fraction purified from the crude MNCs have been preclinically applied for ischemic cardiovascular diseases including PAD. The promising results from these experimental studies in rodents promoted the initiation of clinical pilot trials.

BM-MNCs: As shown in Table 1, a number of clinical trials of BMMNC therapy have ranged from small, pilot to randomized, placebocontrolled trials. BM-derived MNCs are usually separated by density gradient centrifugation or plasmapheresis.

In 2002, the first set of clinical trials of intramuscular implantation of BM-MNCs in patients with PAD was reported [46]. BM-MNC therapy resulted in improvement of rest pain, $\mathrm{ABPI}, \mathrm{TCPO}_{2}$, and painfree walking distance at 24 week follow up compared with baseline. Improvement in rest pain, ulcer size, and pain-free walking distance maintained at 2 years after BM-MNC therapy [47]. A multicenter, randomized, double-blind, placebo-controlled trial is the PROVASA (Intraarterial Progenitor Cell Transplantation of Bone Marrow Mononuclear Cells for Induction of Neovascularization in Patients with Peripheral Arterial Occlusive Disease) trial [48]. A total of 40 patients with CLI were enrolled, received either intraarterial administration of BM-MNCs or placebo, and at the end of 3 months, the placebo group were crossed over to active treatment (an initial administration of BM-MNCs) and the active group received the second administration of BM-MNCs. This study demonstrated the dosedependent improvement in ulcer healing and significant reduction in rest pain, despite no difference in limb salvage rate, amputation-free survival and the primary end point which was an increase in ABPI 
Citation: Fujita Y, Kawamoto A (2014) Cell-Based Therapies for Peripheral Arterial Disease. J Stem Cell Res Ther 4: 234. doi:10.4172/21577633.1000234

Page 3 of 10

\begin{tabular}{|c|c|c|c|c|c|c|c|c|}
\hline \multirow{2}{*}{ Trial name/Author } & \multirow{2}{*}{ Year } & \multirow{2}{*}{ Study design } & \multicolumn{3}{|c|}{ Number of patients } & \multirow{2}{*}{$\begin{array}{c}\text { Route of } \\
\text { administration }\end{array}$} & \multirow{2}{*}{$\begin{array}{l}\text { Follow-up } \\
\text { duration }\end{array}$} & \multirow{2}{*}{ Outcomes } \\
\hline & & & Total & Treated & Control & & & \\
\hline $\begin{array}{c}\text { TACT } \\
\text { Tateishi-Yuyama et } \\
\text { al. [46] }\end{array}$ & 2002 & $\begin{array}{l}\text { Patient series } \\
\text { RCT }\end{array}$ & 45 & $\begin{array}{c}45 \\
25 \text { BM-MNCs } \\
20 \text { PB-MNCs }\end{array}$ & 0 & $\mathrm{IM}$ & 24 weeks & $\begin{array}{l}\mathrm{ABPI} \uparrow, \mathrm{TCPO}_{2} \uparrow \\
\text { Pain-free walking time } \uparrow\end{array}$ \\
\hline Higashi et al. [93] & 2004 & Patient series & 7 & 7 & 0 & $\mathrm{IM}$ & 4 weeks & $\begin{array}{l}\mathrm{TcPO}_{2} \uparrow \\
\text { Pain-free walking time } \uparrow \\
\text { Blood flow response to acetylcholine } \uparrow\end{array}$ \\
\hline Miyamoto et al. [94] & 2006 & Patient series & 8 & 8 & 0 & $\mathrm{IM}$ & 2 years & $\begin{array}{l}\text { Rest pain scale } \downarrow \text {, } \\
\text { Ulcer healing } \uparrow \\
\text { (at } 4 \text { weeks) } \\
\text { Sudden death }(n=1) \text {, } \\
\text { Skin ulcer }(n=1) \text {, } \\
\text { Rest pain }(n=1), \text { Arteriovenous shunt } \\
(n=1) \text { (Long-term) }\end{array}$ \\
\hline Motukuru et al. [95] & 2008 & Patient series & 36 & 36 & 0 & $\mathrm{IM}$ & 6 months & $\begin{array}{l}\mathrm{ABPI} \uparrow, \mathrm{TcPO}_{2} \uparrow \\
\text { Ulcer healing } \uparrow\end{array}$ \\
\hline De Vriese et al. [96] & 2008 & Patient series & 16 & 16 & 0 & $\mathrm{IM}$ & 12 weeks & $\begin{array}{l}\mathrm{ABPI} \rightarrow, \mathrm{TcPO}_{2} \uparrow \\
\text { Rest pain scale } \downarrow \text {, } \\
\text { Muscle capillary density } \uparrow\end{array}$ \\
\hline Cobellis et al. [97] & 2008 & Patient series & 10 & 10 & 0 & IA & 12 months & $\begin{array}{l}\text { ABPI } \uparrow, \\
\text { Pain-free walking distance } \uparrow \text {, } \\
\text { Rest pain scale } \downarrow \text {, } \\
\text { Blood flow } \uparrow \\
\text { Capillary density } \uparrow\end{array}$ \\
\hline Chochola et al. [98] & 2008 & Patient series & 24 & 24 & 0 & $\mathrm{IM}$ & 1 year & $\begin{array}{l}\text { Fontaine grade } \downarrow \text {, } \\
\text { Ulcer healing } \uparrow, \\
\text { Collateral vessel } \uparrow, \text { QOL } \uparrow\end{array}$ \\
\hline Franz et al. [99] & 2009 & Patient series & 9 & 9 & 0 & $I M+I A$ & 3 months & $\begin{array}{l}\mathrm{ABPI} \rightarrow \text {, Rest pain scale } \rightarrow, \\
\text { Limb salvage } \rightarrow\end{array}$ \\
\hline $\begin{array}{c}\text { BONMOT-1 } \\
\text { Amman et al. [100] }\end{array}$ & 2009 & Patient series & 51 & 51 & 0 & $\mathrm{IM}$ & 6 months & $\begin{array}{l}\text { Rutherford's category } \downarrow, \mathrm{ABPI} \uparrow, \mathrm{TcPO}_{2} \uparrow \text {, } \\
\text { Ulcer healing } \uparrow, \\
\text { Total walking distance } \uparrow\end{array}$ \\
\hline Prochazka et al. [101] & 2010 & $\begin{array}{c}\text { RCT } \\
\text { non- } \\
\text { blinded }\end{array}$ & 96 & 42 & 54 & IA & 120 days & Limb salvage $\uparrow$, \\
\hline $\begin{array}{c}\text { PROVASA } \\
\text { Walter et al. [48] }\end{array}$ & 2011 & $\begin{array}{l}\text { RCT } \\
\text { double- } \\
\text { blind } \\
\text { crossover }\end{array}$ & 40 & 19 & 21 & IA & 6 months & $\begin{array}{l}\text { Ulcer healing } \uparrow, \text { Rest pain scale } \downarrow \text {, } \\
\text { ABPI } \rightarrow \text {, Limb salvage } \rightarrow\end{array}$ \\
\hline $\begin{array}{l}\text { Ruiz-Salmeron et al. } \\
\qquad[102]\end{array}$ & 2011 & Patient series & 20 & 20 & 0 & IA & 12 months & $\begin{array}{l}\text { ABPI } \uparrow, \text { Wound healing } \uparrow \text {, } \\
\text { Angiographic blood flow } \uparrow \\
\text { (at } 3 \text { months) }\end{array}$ \\
\hline Murphy et al. [103] & 2011 & Patient series & 29 & 29 & 0 & $\mathrm{IM}$ & 1 year & $\begin{array}{l}\text { FTP } \uparrow, \text { TBPI } \uparrow, \\
\text { Rest pain scale } \downarrow, \mathrm{QOL} \uparrow \text { (at } 12 \text { weeks) }\end{array}$ \\
\hline Idei et al. [104] & 2011 & Cohort & 97 & 51 & 46 & $\mathrm{IM}$ & 3 years & $\begin{array}{l}\text { Amputation-free survival } \uparrow \\
\mathrm{ABPI} \uparrow, \mathrm{TcPO}_{2} \uparrow \text { in patients with } \mathrm{TAO} . \\
\mathrm{ABPI} \rightarrow, \mathrm{TcPO}_{2} \rightarrow \text { in patients with } \\
\text { Atherosclerotic PAD. }\end{array}$ \\
\hline Benoit et al. [105] & 2011 & $\begin{array}{l}\text { RCT } \\
\text { double- } \\
\text { blind }\end{array}$ & 48 & 34 & 14 & $\mathrm{IM}$ & 6 months & Amputation rate $\downarrow$ \\
\hline Klepanec et al. [106] & 2012 & Patient series & 41 & 41 & 0 & $\begin{array}{c}\text { IM }(n=21), \mid A \\
(n=20)\end{array}$ & 6 months & $\begin{array}{l}\text { Rutherford's category } \downarrow \text {, } \\
\mathrm{TcPO}_{2} \uparrow \text {, } \\
\text { Rest pain scale } \downarrow \text {, QOL } \uparrow\end{array}$ \\
\hline
\end{tabular}

ABPI indicates ankle brachial pressure index; BM, bone marrow; CLI, critical limb ischemia; FTP, first toe pressure; IA, intra-arterial; IM, intramuscular; MNC, mononuclea cell; PAD, peripheral arterial disease; PB, peripheral blood; $\mathrm{QOL}$, quality of life; RCT, randomized controlled trial; TAO, thromboangitis obliterance; TcPO, transcutaneous oxygen pressure.

Table 1: Clinical trials of autologous BM-MNC administration for CLI.

between the groups. Furthermore, patients with Rutherford's category 6 (extensive gangrene and impending amputation) CLI at baseline did not respond to administration of BM-MNCs. All these patients underwent major amputation within 3 months after treatment, presumably owing to too far progression, which is the characteristic of advanced staged CLI. Administration of BM-MNCs may not be suitable for Rutherford's category 6 CLI. The PROVASA investigators speculated that the choice of change in ABPI as the primary endpoint was not appropriate for this study because the change of ABPI did not correlate with improvements in the clinically most relevant secondary endpoints including ulcer healing and rest pain reduction. The discordance between clinical endpoints and functional endpoints like ABPI, TBPI or TcPO2 was similarly reported in a gene therapy trial for therapeutic angiogenesis in CLI [25] and remains a cardinal issue in design and execution of clinical trials in CLI. To establish the appropriate endpoints for cell therapy trials, various characteristics of cell therapy, as distinct from conventional revascularization including bypass surgery and endovascular intervention, should be considered. 
Currently, 2 phase III clinical trials are ongoing (ClinicalTrials.gov NCT01245335; NCT01818310). In these clinical trials, a hard endpoint including amputation-free survival is selected as a primary endpoint.

G-CSF-mobilized PB-MNCs: G-CSF-mobilized PB-MNCs have been also investigated in CLI as shown in Table 2. PB-MNCs are usually mobilized using several doses of subcutaneous G-CSF and harvested by plasmapheresis. Both intramuscular and intraarterial injections of unfractionated mobilized PB-MNCs improved ABPI and maximum walking distance in small clinical trials [49-52]. A phase III clinical trial is ongoing (ClinicalTrials.gov NCT 01833585), and the final results may provide a definitive evidence of clinical usefulness of this cell-based therapy in CLI.

Huang et al. compared the therapeutic effect of intramuscular administration of BM-MNCs with G-CSF-mobilized PB-MNCs in patients with CLI [53]. One hundred fifty patients with CLI were randomized to receive intramuscular injection of BM-MNCs or G-CSF-mobilized MNCs. At 12 weeks after therapy, improvement of $\mathrm{ABPI}$, skin temperature and rest pain was significantly greater in PBMNC group than BM-MNC group despite no difference in pain-free walking distance, ulcer healing, and amputation rates between the 2 groups (Table 3). Further studies comparing the therapeutic potential between the different types of cell therapies would be intriguing.

Non-mobilized PB-MNCs: Tateno et al. reported the results of a pilot clinical trial of intramuscular injection of non-mobilized PBMNCs in patients with CLI [54]. In this study, 29 patients with CLI caused by atherosclerotic PAD or TAO received intramuscular injection of PB-MNCs twice within 1-month period. Rest pain was significantly improved until 2 months after treatment, and maximal walking distance significantly increased until 6 months. These improvements were preserved for 12 months (Table 2). Furthermore, a long-term retrospective study demonstrated that intramuscular injection of non-mobilized PB-MNCs for CLI might be safe and potentially effective. However, improvement of ischemic symptoms was less in atherosclerotic PAD patients on hemodialysis compared with nonhemodialysis PAD or TAO patients. Major adverse events including death, major amputation and cardiovascular events frequently occurred in PAD patients on hemodialysis [55]. Horie et al. also demonstrated that PAD patients on hemodialysis had a worse prognosis than nonhemodialysis PAD patients after intramuscular administration of G-CSF-mobilized PB-MNCs [56]. Choi et al. demonstrated that the number and functional activity of EPCs decreased in patients with end-stage renal disease [57]. To overcome the therapeutic limitation in PAD patients on hemodialysis, novel strategies such as transplantation of other type of stem/progenitor cells or cell culture for quantitative expansion and qualitative improvement may be required.

Fractionated EPCs (CD34+/ CD133+/ aldehyde dehydrogenase bright $\left(\mathrm{ALDH}^{\mathrm{br}}\right)$ cells): BM-derived EPCs comprise a small fraction (0.1-2\%) of total MNCs. The advantage of the administration of fractionated EPCs is a higher concentration of EPCs compared with that of crude MNCs resulting in greater therapeutic potency. Onodera et al. reported that treatment with small number of harvested CD34+ cells was a negative independent predictor of amputation and death following either BM- or PB-MNC implantation in patients with CLI [58]. This finding suggests an important role of EPCs for therapeutic neovascularization and may provide a reasonable rationale for transplantation of $\mathrm{CD} 34+$ cells purified from crude MNCs in patients with CLI.

In a phase I/IIa clinical trial, our group evaluated the safety and feasibility of G-CSF-mobilized CD34+ cells in no-option patients with atherosclerotic PAD or TAO representing CLI [59]. CD34+ cells were isolated from the G-CSF-mobilized apheresis product using a magnetic cell sorting system, and then intramuscularly transplanted in a dose-

\begin{tabular}{|c|c|c|c|c|c|c|c|c|c|}
\hline \multirow{2}{*}{ Trial name/Author } & \multirow{2}{*}{ Year } & \multirow{2}{*}{ Study design } & \multicolumn{3}{|c|}{ Number of patients } & \multirow{2}{*}{ Product } & \multirow{2}{*}{$\begin{array}{c}\text { Route of } \\
\text { administration }\end{array}$} & \multirow{2}{*}{$\begin{array}{l}\text { Follow-up } \\
\text { duration }\end{array}$} & \multirow{2}{*}{ Outcomes } \\
\hline & & & Total & Treated & Control & & & & \\
\hline Huang et al. [107] & 2004 & Patient series & 5 & 5 & 0 & $\begin{array}{l}\text { G-CSF-mobilized PB- } \\
\text { MNCs }\end{array}$ & IM & 3 months & $\begin{array}{l}\text { ABPI } \uparrow \\
\text { Laser Doppler blood perfusion } \uparrow\end{array}$ \\
\hline Ishida et al. [49] & 2005 & Patient series & 6 & 6 & 0 & $\begin{array}{l}\text { G-CSF-mobilized PB- } \\
\text { MNCs }\end{array}$ & IM & 24 weeks & $\begin{array}{l}\mathrm{ABPI} \rightarrow \mathrm{TcPO}_{2} \rightarrow \\
\text { Maximal walking distance } \uparrow\end{array}$ \\
\hline Huang et al. [51] & 2005 & $\begin{array}{l}\text { RCT, non- } \\
\text { blinded }\end{array}$ & 28 & 14 & 14 & $\begin{array}{c}\text { G-CSF-mobilized PB- } \\
\text { MNCs }\end{array}$ & $\mathrm{IM}$ & 3 months & $\begin{array}{l}\text { ABPI } \uparrow \text {, } \\
\text { Laser Doppler blood perfusion } \uparrow, \text { Ulcer } \\
\text { healing } \uparrow \\
\text { Angiographic score } \uparrow\end{array}$ \\
\hline Lenk et al. [50] & 2005 & Patient series & 7 & 7 & 0 & $\begin{array}{l}\text { G-CSF-mobilized PB- } \\
\text { MNCs }\end{array}$ & IA & 12 weeks & $\begin{array}{l}\mathrm{ABPI} \uparrow, \mathrm{TcPO}_{2} \uparrow, \\
\text { Pain-free walking distance } \uparrow, \\
\text { Flow-dependent vasodilation } \uparrow, \\
\text { Flow reserve in response to adenosine } \uparrow \text {, } \\
\text { Endothelium-dependent vasodilation } \uparrow\end{array}$ \\
\hline $\begin{array}{l}\text { Lara-Hernandez et } \\
\text { al. [52] }\end{array}$ & 2010 & Patient series & 28 & 28 & 0 & $\begin{array}{l}\text { G-CSF-mobilized PB- } \\
\text { MNCs }\end{array}$ & IM & 14 months & $\begin{array}{l}\text { ABPI } \uparrow, \text { Rest pain scaled } \downarrow \text {, } \\
\text { Limb salvage } \uparrow\end{array}$ \\
\hline Tateno et al. [54] & 2006 & Patient series & 29 & 29 & 0 & non-mobilized PB-MNCs & $\mathrm{IM}$ & 12 months & $\begin{array}{l}\text { Rest pain scale } \uparrow \text {, } \\
\text { Maximal walking distance } \uparrow\end{array}$ \\
\hline
\end{tabular}

G-CSF indicates granulocyte-colony stimulating factor.

Table 2: Clinical trials of autologous G-CSF-mobilized PB-MNC therapy and non-mobilized PB-MNC administration for CLI.

\begin{tabular}{|c|c|c|c|c|c|c|c|c|c|}
\hline \multirow{2}{*}{$\begin{array}{l}\text { Trial name } \\
\text { /Author }\end{array}$} & \multirow{2}{*}{ Year } & \multirow{2}{*}{$\begin{array}{l}\text { Study } \\
\text { design }\end{array}$} & \multicolumn{3}{|c|}{ Number of patients } & \multirow{2}{*}{ Product } & \multirow{2}{*}{$\begin{array}{c}\text { Route of } \\
\text { administration }\end{array}$} & \multirow{2}{*}{$\begin{array}{l}\text { Follow-up } \\
\text { duration }\end{array}$} & \multirow{2}{*}{ Outcomes } \\
\hline & & & Total & Treated & Control & & & & \\
\hline $\begin{array}{c}\text { Huang et al. } \\
{[53]}\end{array}$ & 2007 & $\mathrm{RCT}$ & 150 & 150 & 0 & $\begin{array}{c}\text { BM-MNCs }(n=74) \\
\text { G-CSF-mobilized PB- } \\
\text { MNCs } \\
(n=76)\end{array}$ & $\mathrm{IM}$ & 12 weeks & $\begin{array}{l}\text { ABPI } \uparrow, \text { Skin temperature } \uparrow, \\
\text { Rest pain scale } \downarrow \text { in the G-CSF-mobilized } \\
\text { PB-MNC treated group. } \\
\text { No significant difference in } \mathrm{TcPO}_{2}, \\
\text { pain-free walking distance, } \\
\text { Ulcer healing and amputation rate. }\end{array}$ \\
\hline
\end{tabular}

Table 3: Clinical trials of autologous BM-MNCs versus G-CSF-mobilized PB-MNCs for CLI. 
escalating manner into 17 patients $\left(10^{5} / \mathrm{kg}, \mathrm{n}=6 ; 5 \times 10^{5} / \mathrm{kg}, \mathrm{n}=8\right.$; or $\left.10^{6} / \mathrm{kg}, \mathrm{n}=3\right)$. CD34+ cell therapy significantly improved Rutherford's category, pain scale, and skin ulcer size and blood perfusion at 12 weeks after treatment; although no significant dose-response relationship was observed. Furthermore, the safety and efficacy of CD34+ cell therapy was sustained for up to 4 years after cell therapy [60]. Furthermore, our phase II trial almost reproduced the clinical outcomes in the previous phase I/IIa trial, indicating the safety, feasibility and potential effectiveness of CD34+ cell transplantation for CLI patients [61]. Recently, in the ACT34-CLI (Autologous CD34+ Cell Therapy for Critical Limb Ischemia Investigator) study, a double-blind, randomized, placebo-controlled, phase I/IIa pilot clinical trial, 28 patients with CLI were randomized to receive intramuscular injection of $1 \times 10^{5}$ (lowdose, $\mathrm{n}=7$ ) or $1 \times 10^{6}$ (high-dose, $\mathrm{n}=9$ ) cells $/ \mathrm{kg}$ of mobilized CD34+ cells or an equal volume of diluent [62]. A favorable trend towards improvement of amputation-free survival rate was observed in the cell-treated groups, especially in the high-dose group, compared with control group at 6 and 12 months after treatment (Table 4).

In a phase I trial, Burt et al. evaluated the safety and feasibility of intramuscular implantation of autologous G-CSF-mobilized CD133+ cells, another EPC-enriched fraction, in 9 patients with CLI [63]. In this uncontrolled study, leg amputation was observed in 2 out of 9 patients at 12 months after treatment. The 7 amputation-free patients showed significant improvement in QOL score at 3 and 6 months, but not 12 months. There was a favorable trend towards improvement in painfree walking distance and exercise capacity at 12 months (Table 4).

Storms et al. developed a method of isolation and purification of stem/progenitor cells based on the specific cell function. They isolated a very primitive population, Lin-CD34+CD38lo/- of HSCs from human cord blood, using a fluorescent substrate for the cytosolic aldehyde dehydrogenase (ALDH), which is expressed at high level in HSCs [64]. These cells, referred to ALDH-bright $\left(\mathrm{ALDH}^{\mathrm{br}}\right)$ cells, were also isolated from human $\mathrm{BM}$ and $\mathrm{PB}$. Gentry et al. demonstrated that $\mathrm{ALDH}^{\text {br }}$ cells derived from human BM showed more hematopoietic colony forming activity and generated more endothelial colonies compared with $\mathrm{ALDH}^{\mathrm{br}}$ cells-depleted BM-MNCs [65]. A preclinical study demonstrated that intravenous administration of human BMderived $\mathrm{ALDH}^{\mathrm{br}}$ cells was more effective for promoting angiogenesis and restoring blood flow than BM-MNCs or $\mathrm{ALDH}^{\text {dim }}$ cells in immunodeficient mice with hindlimb ischemia [66].

In a phase I/II randomized, controlled trial of $\mathrm{ALDH}^{\text {br }}$ cell therapy for patients with CLI, 21 patients were randomized to receive intramuscular injection of $\mathrm{BM}$-derived $\mathrm{ALDH}^{\text {br }}$ cells $(\mathrm{n}=11)$ or $\mathrm{BM}$ MNCs ( $n=10)$ [67]. No therapy-related serious adverse events were observed. At 12 weeks after treatment, Rutherford's category and ABPI significantly improved compared with baseline in the $\mathrm{ALDH}^{\text {br }}$ treated group but not in the BM-MNC treated group. However, there was no significant change in ischemic ulcer grade and $\mathrm{TcPO}_{2}$ in either group (Table 4).

Larger randomized clinical trials are warranted to clarify the efficacy of EPCs fractionated by various methods for the treatment of PAD patients.

\section{Mesenchymal stem cells (MSCs)}

Mesenchymal stem cells (MSCs) are a subset of stem cells which exist in the BM stroma and can differentiate into the mesenchymal lineages, including osteoblasts, chondrocytes, myoblasts, and adipocytes [68]. MSCs can be distinguished from BM hematopoietic cells by their ability to adhere to the culture dish [69]. No specific markers of MNCs exist. However, it is generally recognized that MSCs express CD105, CD73, CD44, CD90, CD71, and Stro-1 and cell adhesion molecules VCAM-1 and ICAM-1, but not hematopoietic markers CD45, CD34, CD14 or CD11 [70]. MSCs have been demonstrated to be an attractive source of cell therapy for the treatment of ischemic diseases [71-73].

Umbilical cord MSCs, BM-MSCs and Ixmyelocel-T: The first clinical trial of intramuscular administration of allogeneic human umbilical cord-derived MSCs has shown that allogeneic umbilical cord-derived MSC therapy improved ulcer healing time and rest pain, and increased capillary formation in 4 patients with TAO [74]. Dash et al. reported that intramuscular injection of autologous BM-derived MSCs in patients with non-healing ulcers of lower limb accelerated ulcer healing and improved pain-free walking distance [75]. Recent clinical trials have used combination cell product, BM-MSCs and BMMNCs. Lasala et al. reported a phase II clinical trials of a combination cell therapy in patients with limb ischemia [76]. In this study, 26 patients received intramuscular injection of a combination of up to $30 \times 10^{6}$ BM-MSCs and $30 \times 10^{8}$ BM-MNCs into the more ischemic leg and a placebo product into the less ischemic contralateral leg. Walking time and ABPI significantly improved. Technetium-99m-tetrofosmin scintigraphy demonstrated that blood flow of the treated limbs significantly increased compared with the contralateral control legs. On the other hand, Lu et al. compared the therapeutic effect of BM-

\begin{tabular}{|c|c|c|c|c|c|c|c|c|c|}
\hline \multirow{2}{*}{$\begin{array}{l}\text { Trial name } \\
\text { IAuthor }\end{array}$} & \multirow{2}{*}{ Year } & \multirow{2}{*}{ Study design } & \multicolumn{3}{|c|}{ Number of patients } & \multirow{2}{*}{ Product } & \multirow{2}{*}{$\begin{array}{c}\text { Route of } \\
\text { administration }\end{array}$} & \multirow{2}{*}{$\begin{array}{c}\text { Follow-up } \\
\text { duration }\end{array}$} & \multirow{2}{*}{ Outcomes } \\
\hline & & & Total & Treated & Control & & & & \\
\hline $\begin{array}{l}\text { Kawamoto et al. [59] } \\
\text { Kinoshita et al. [60] }\end{array}$ & 2009 & Patient series & 17 & 17 & 0 & $\begin{array}{l}\text { G-CSF-mobilized } \\
\text { CD34+ cells }\end{array}$ & $\mathrm{IM}$ & 52 weeks & $\begin{array}{l}\text { Efficacy score (TBPI, Rest pain scale, } \\
\text { Total walking distance) } \uparrow\end{array}$ \\
\hline $\begin{array}{c}\text { ACT34-CLI } \\
\text { Losordo et al. [62] }\end{array}$ & 2012 & $\begin{array}{l}\text { RCT } \\
\text { double- } \\
\text { blind }\end{array}$ & 28 & 16 & 12 & $\begin{array}{l}\text { G-CSF-mobilized } \\
\text { CD34+ cells }\end{array}$ & IM & 12 months & $\begin{array}{l}\text { Amputation rate } \downarrow(p=0.058) \text { compared } \\
\text { with control }\end{array}$ \\
\hline Fujita et al. [61] & 2014 & Patient series & 11 & 11 & 0 & $\begin{array}{l}\text { G-CSF-mobilized } \\
\text { CD34+ cells }\end{array}$ & IM & 52 weeks & $\begin{array}{l}\text { Rutherford's category } \uparrow \text {, } \\
\text { Rest pain scales } \downarrow \text {, } \\
\text { Skin perfusion pressure } \uparrow \text {, } \\
\text { TBPI } \uparrow, \mathrm{TcPO}_{2} \uparrow \\
\text { Pain-free walking distance } \uparrow \text {, } \\
\text { Total walking distance } \uparrow\end{array}$ \\
\hline Burt et al. [63] & 2010 & Patient series & 9 & 9 & 0 & $\begin{array}{l}\text { G-CSF-mobilized } \\
\text { CD133+ cells }\end{array}$ & IM & 12 months & $\mathrm{QOL} \uparrow$ (at 6 months) \\
\hline Perin et al. [67] & 2011 & RCT & 21 & 21 & 0 & $\begin{array}{c}\text { ALDH }^{\text {br }} \\
(n=11) \\
\text { BM-MNCs }(n=10)\end{array}$ & IM & 12 weeks & $\begin{array}{l}\text { Rutherford's category } \downarrow \text {, } \\
\text { ABPI } \uparrow \text { in the ALDH }{ }^{\text {br }} \text { treated group. }\end{array}$ \\
\hline
\end{tabular}

$\mathrm{ALDH}^{\mathrm{br}}$ indicates aldehyde dehydrogenase bright; EPCs, endothelial progenitor cells; TBPI, toe brachial pressure index.

Table 4: Clinical trials of fractionated EPCs (CD34+/ CD133+/ ALDH ${ }^{\text {br }}$ cells) therapy for CLI. 
MSCs with BM-MNCs in 20 diabetic patients with bilateral CLI [77]. They demonstrated that the ulcer healing rate was significantly higher in BM-MSC group than BM-MNC group at 6 weeks after treatment and achieved complete ulcer healing 4 weeks earlier in BM-MSC group than BM-MNC group. At 24 weeks, pain-free walking time, ABPI and $\mathrm{TcPO}_{2}$ significantly improved in BM-MSC group compared with BM$\mathrm{MNC}$ group. However, there was no significant difference between the groups in terms of pain relief and amputation (Table 5).

Ixmyeloid-T is generated in a closed and automated culture system that expands the number ofCD $90+$ mesenchymal and CD14+ monocytic stem/progenitor cells obtained from a small amount of a patient's own BM [78]. In the phase II, prospective, randomized, double-blind, RESTORE-CLI (Use of Tissue Repair Cells in Patients with Peripheral Arterial Disease to Treat Critical Limb Ischemia) trial [79], a total of 46 patients with CLI were randomized to receive intramuscular injection of Ixmyelocel-T or placebo. By the time of interim analysis, 33 patients completed the 12-month follow-up and 13 patients completed at least 6 months of follow-up. Ixmyelocel-T treatment resulted in a significantly prolonged time to the first occurrence of treatment failure defined as major amputation, all-cause mortality, doubling of the total wound surface area from baseline, or de novo gangrene. There was a trend towards improvement of amputation-free survival after Ixmyeloid-T treatment; however the difference was not statistically significant (Table 5). Following the promising results, a pivotal phase III clinical trial, REVIVE (ClinicalTrials.gov NCT 01483898) has started, although this study ended recently due to slow recruitment of the CLI patients.

Further clinical trials will be required to identify the clinical usefulness of MSCs in patients with PAD.

Adipose-derived stem/progenitor cells (ADSCs): Adipose tissue has been also represented as a cell source for therapeutic angiogenesis in ischemic diseases. Adipose tissue is mainly composed of two classes of cells. One is mature adipocyte, which forms the major part of adipose tissue volume. The other is stromal cell termed stromal vascular fraction (SVF) [80]. Several studies have revealed that SVF contains multipotent mesenchymal stem/progenitor cells, which have the capability to differentiate into various lineages including adipocytes, fibroblasts, osteoblasts, chondrocytes, pericytes and myocytes $[81,82]$. Recently, mesenchymal stem cells in adipose tissue are named adiposederived stem/progenitor cells (ADSCs or ASCs) or adipose-derived regenerative cells (ADRCs) which have the capability of regenerating injured tissue [80]. The advantage of ADSCs is that they can be isolated from a small amount of human subcutaneous adipose tissue through minimally invasive procedures including liposuction and excision of subcutaneous adipose tissue and expanded ex vivo [82]. Several studies demonstrated that the transplantation of ADSCs increased angiogenesis in rodent models of hindlimb ischemia [83,84]. However, the mechanism underlying neovascularization induced by ADSCs has not been fully understood. Traktuev et al. reported that ADSCs could not differentiate into EPCs or endothelial cells, but that ADSCs could differentiate into pericytes and play a role in vascular stabilization [85]. Recent studies have shown that ADSCs can secrete multiple pro-angiogenic growth factors and cytokines including VEGF, HGF and SDF-1 $[83,84,86,87]$. In particular, SDF-1 is thought to play a pivotal role in ADSC-mediated angiogenesis via acceleration of EPCs recruitment into ischemic foci [84].

The first phase I clinical trial, ACellDREAM (Adipose CELL Derived Regenerative Endothelial Angiogenic Medicine) study was reported in 2014 [88], in which 7 patients with no-option CLI received intramuscular injection of autologous ADSCs. ADSC injection resulted

\begin{tabular}{|c|c|c|c|c|c|c|c|c|c|}
\hline \multirow{2}{*}{$\begin{array}{l}\text { Trial name } \\
\text { IAuthor }\end{array}$} & \multirow{2}{*}{ Year } & \multirow{2}{*}{$\begin{array}{l}\text { Study } \\
\text { design }\end{array}$} & \multicolumn{3}{|c|}{ Number of patients } & \multirow{2}{*}{ Product } & \multirow{2}{*}{$\begin{array}{c}\text { Route of } \\
\text { administration }\end{array}$} & \multirow{2}{*}{$\begin{array}{l}\text { Follow-up } \\
\text { duration }\end{array}$} & \multirow{2}{*}{ Outcomes } \\
\hline & & & Total & Treated & Control & & & & \\
\hline Kim et al. [74] & 2006 & $\begin{array}{l}\text { Patient } \\
\text { series }\end{array}$ & 4 & 4 & 0 & $\begin{array}{c}\text { HLA matched } \\
\text { UCB-derived MSCs }\end{array}$ & SC or IM & 4 months & $\begin{array}{l}\text { Rest pain } \uparrow \text { swithin } 14 \text { days, } \\
\text { Wound healing } \uparrow \text { uwithin } 120 \text { days, } \\
\text { Angiographic collateral vessels } \uparrow\end{array}$ \\
\hline Dash et al. [75] & 2009 & $\mathrm{RCT}$ & 24 & 12 & 12 & BM-MSCs & IM & 12 weeks & $\begin{array}{l}\text { Pain-free walking distance } \uparrow \text {, } \\
\text { Ulcer size } \downarrow\end{array}$ \\
\hline Lu et al. [77] & 2011 & $\begin{array}{l}\text { RCT } \\
\text { double- } \\
\text { blind }\end{array}$ & $\begin{array}{c}41 \\
(82 \text { limbs) }\end{array}$ & 41 limbs & 41 limbs & $\begin{array}{l}\text { BM-MSCs } \\
(20 \text { limbs }) \\
\text { BM-MNCs } \\
(21 \text { limbs) }\end{array}$ & $\mathrm{IM}$ & 24 weeks & $\begin{array}{l}\text { BM-MSCs vs Control } \\
\text { ABPI } \uparrow, T c P \mathrm{O}_{2} \uparrow, \\
\text { Rest pain scale } \downarrow \text {, } \\
\text { Pain-free walking time } \uparrow \text {, } \\
\text { Angiographic score } \uparrow, \\
\text { Ulcer healing } \uparrow \\
\text { BM-MSC vs BM-MNCs } \\
\text { ABPI } \uparrow, T c P O_{2} \uparrow, \\
\text { Rest pain scale } \downarrow \text {, } \\
\text { Pain-free walking time } \uparrow \text {, } \\
\text { Angiographic score } \uparrow, \\
\text { Ulcer healing } \uparrow, \\
\text { Rest pain scale } \rightarrow \text {, } \\
\text { Amputation rate } \rightarrow\end{array}$ \\
\hline Lasala et al. [108] & 2010 & $\begin{array}{l}\text { Patient } \\
\text { series }\end{array}$ & 10 & 10 & 0 & $\begin{array}{l}\text { BM-MSCs } \\
+ \text { BM-MNCs }\end{array}$ & IM & 10 months & $\begin{array}{l}\text { Total walking time } \uparrow \text {, } \\
\text { ABPI } \uparrow, Q O L \uparrow\end{array}$ \\
\hline Lasala et al. [76] & 2012 & $\begin{array}{l}\text { Patient } \\
\text { series }\end{array}$ & 26 & 26 limbs & 26 limbs & $\begin{array}{l}\text { BM-MSCs } \\
+\mathrm{BM}-\mathrm{MNCs}\end{array}$ & $\mathrm{IM}$ & 4 months & $\begin{array}{l}\text { ABPI } \uparrow, \\
\text { Total walking time } \uparrow, \\
\text { QOL } \uparrow, \\
\text { Scintigraphic limb perfusion } \uparrow\end{array}$ \\
\hline $\begin{array}{l}\text { RESTORE-CLI } \\
\text { Powell et al. [79] }\end{array}$ & 2011 & RCT & 46 & 32 & 14 & Ixmyelocel-T & $\mathrm{IM}$ & $\begin{array}{l}6 \text { months } \\
12 \text { months }\end{array}$ & $\begin{array}{l}\text { Amputation-free suivival } \uparrow \\
\text { Ulcer healing } \uparrow\end{array}$ \\
\hline $\begin{array}{l}\text { ACellDREAM } \\
\text { Bura et al. [88] }\end{array}$ & 2014 & $\begin{array}{l}\text { Patient } \\
\text { series }\end{array}$ & 7 & 7 & 0 & ADSCs & $\mathrm{IM}$ & 6 months & $\begin{array}{l}\mathrm{TcPO}_{2} \uparrow \\
\text { Ulcer healing } \uparrow\end{array}$ \\
\hline
\end{tabular}

ADSC indicates adipose-derived stem cell; HLA, human leukocyte antigen; MSC, mesenchymal stem cell; SC, subcutaneous; UCB, umbilical cord blood. 
in improvement of $\mathrm{TcPO}_{2}$ and wound healing (Table 5). Several phase I/II clinical trials of ADSCs for CLI are ongoing.

\section{Meta-analysis of BM-derived cell trials in patients with CLI}

Recently, Teraa et al. performed a meta-analysis of 12 randomized clinical trials (RCTs) of BM-derived cell therapy in patients with CLI [89]. This meta-analysis studied BM-derived cell therapy, including 7 trials using BM-MNCs, 3 trials using BM-MSCs, 2 trials using G-CSF-mobilized MNCs and 1 trial using Ixmyelocel-T, comparing with standard of care groups with or without placebo in a total of 510 patients with CLI. This meta-analysis demonstrated that BM-derived cell therapy resulted in beneficial effects on major amputation rate and subjective and objective surrogate endpoints including pain score, pain-free walking distance, $\mathrm{ABPI}$ and $\mathrm{TcPO}_{2}$. However, amputationfree survival did not significantly differ between the treated group and the control group. Subgroup analysis revealed that in the 7 placebocontrolled RCTs including 4 trials using BM-MNCs, 1 trial using BM-MSCs, 1 trial using G-CSF-mobilized MNCs and 1 trial using Ixmyelocel- $\mathrm{T}$, the beneficial effect on major amputation rate was reduced and was not significant.

\section{Conclusions}

Summarizing the results of the previous clinical trials, stem/ progenitor cell therapies may be safe and feasible. Theoretically, stem/ progenitor cell therapies may be superior over protein or gene therapy due to not only direct vasculogenic properties but also paracrine action by secreting multiple growth factors besides a single angiogenic factor.

Early phase clinical trials revealed the efficacy of BM-MNCs, G-CSF-mobilized PB-MNCs and BM-MSCs for CLI. However, a metaanalysis of the early phase RCTs revealed that there was no significant improvement of amputation-free survival in the treatment group compared with the control group, especially in the placebo-controlled trials [89].

Phase I/II trials revealed that intramuscular injection of EPCs (CD34+, CD133+ or ALDH ${ }^{\text {br }}$ cells) for CLI might be safe, feasible and effective. Following these favorable outcomes, a multicenter phase III clinical trial for CD34+ cells is in preparation in our institution.

ADSCs have generated great interest as a new tool of cell therapy, which may be a hopeful strategy for CLI.

In either cell type, well-designed larger placebo-controlled RCTs are warranted to prove the safety, feasibility and efficacy of the cellbased therapies. Guidelines or recommendations for adequate clinical trial methodology such as patient selection criteria, endpoints, and study design, etc. was recently proposed for pharmacotherapy [90], endovascular intervention [91] and bypass surgery [92] in patients with CLI. However, there is a lack of consensus on relevant methodology in the pivotal clinical trials of cell therapy in patients with CLI. It would be also urgently needed to establish such consensus for cell therapy in CLI.

\section{References}

1. Criqui MH, Fronek A, Barrett-Connor E, Klauber MR, Gabriel S, et al. (1985) The prevalence of peripheral arterial disease in a defined population. Circulation 71 : 510-515. [PubMed]

2. Fowkes FG, Housley E, Cawood EH, Macintyre CC, Ruckley CV, et al (1991) Edinburgh Artery Study: prevalence of asymptomatic and symptomatic peripheral arterial disease in the general population. Int J Epidemiol 20: 384392. [PubMed]

3. McDermott MM, Kerwin DR, Liu K, Martin GJ, O'Brien E, et al. (2001) Prevalence and significance of unrecognized lower extremity peripheral arterial disease in general medicine practice*. J Gen Intern Med 16: 384-390. [PubMed]

4. Belch JJ, Topol EJ, Agnelli G, Bertrand M, Califf RM, et al. (2003) Critical issues in peripheral arterial disease detection and management: a call to action. Arch Intern Med 163: 884-892. [PubMed]

5. Norgren L, Hiatt WR, Dormandy JA, Nehler MR, Harris KA, et al. (2007) InterSociety Consensus for the Management of Peripheral Arterial Disease (TASC II). J Vasc Surg 45: S5-67. [PubMed]

6. Fadini GP, Agostini C, Avogaro A (2010) Autologous stem cell therapy for peripheral arterial disease meta-analysis and systematic review of the literature. Atherosclerosis 209: 10-17. [PubMed]

7. Sprengers RW, Moll FL, Verhaar MC (2010) Stem cell therapy in PAD. Eur J Vasc Endovasc Surg 39: S38-43. [PubMed]

8. Henry TD, Annex BH, McKendall GR, Azrin MA, Lopez JJ, et al. (2003) The VIVA trial: Vascular endothelial growth factor in Ischemia for Vascular Angiogenesis. Circulation 107: 1359-1365. [PubMed]

9. Lederman RJ, Mendelsohn FO, Anderson RD, Saucedo JF, Tenaglia AN, et al (2002) Therapeutic angiogenesis with recombinant fibroblast growth factor-2 for intermittent claudication (the TRAFFIC study): a randomised trial. Lancet 359: 2053-2058. [PubMed]

10. Seiler C, Pohl T, Wustmann K, Hutter D, Nicolet PA, et al. (2001) Promotion of collateral growth by granulocyte-macrophage colony-stimulating factor in patients with coronary artery disease: a randomized, double-blind, placebocontrolled study. Circulation 104: 2012-2017. [PubMed]

11. Arai M, Misao Y, Nagai H, Kawasaki M, Nagashima K, et al. (2006) Granulocyte colony-stimulating factor: a noninvasive regeneration therapy for treating atherosclerotic peripheral artery disease. Circ J 70: 1093-1098. [PubMed]

12. Poole J, Mavromatis K, Binongo JN, Khan A, Li Q, et al. (2013) Effect of progenitor cell mobilization with granulocyte-macrophage colony-stimulating factor in patients with peripheral artery disease: a randomized clinical trial. JAMA 310: 2631-2639. [PubMed]

13. Tsurumi Y, Takeshita S, Chen D, Kearney M, Rossow ST, et al. (1996) Direct intramuscular gene transfer of naked DNA encoding vascular endothelial growth factor augments collateral development and tissue perfusion. Circulation 94: 3281-3290. [PubMed]

14. Isner JM, Baumgartner I, Rauh G, Schainfeld R, Blair R, et al. (1998) Treatment of thromboangiitis obliterans (Buerger's disease) by intramuscular gene transfer of vascular endothelial growth factor: preliminary clinical results. J Vasc Surg 28: 964-973. [PubMed]

15. Isner JM, Pieczek A, Schainfeld R, Blair R, Haley L, et al. (1996) Clinica evidence of angiogenesis after arterial gene transfer of phVEGF165 in patient with ischaemic limb. Lancet 348: 370-374. [PubMed]

16. Rajagopalan S, Shah M, Luciano A, Crystal R, Nabel EG (2001) Adenovirusmediated gene transfer of VEGF(121) improves lower-extremity endothelial function and flow reserve. Circulation 104: 753-755. [PubMed]

17. Kusumanto $\mathrm{YH}$, van Weel V, Mulder $\mathrm{NH}$, Smit AJ, van den Dungen JJ, et al. (2006) Treatment with intramuscular vascular endothelial growth facto gene compared with placebo for patients with diabetes mellitus and critical limb ischemia: a double-blind randomized trial. Hum Gene Ther 17: 683-691. [PubMed]

18. Rajagopalan S, Mohler ER 3rd, Lederman RJ, Mendelsohn FO, Saucedo JF, et al. (2003) Regional angiogenesis with vascular endothelial growth factor in peripheral arterial disease: a phase II randomized, double-blind, controlled study of adenoviral delivery of vascular endothelial growth factor 121 in patients with disabling intermittent claudication. Circulation 108: 1933-1938. [PubMed]

19. Muona K, Makinen K, Hedman M, Manninen H, Yla-Herttuala S (2012) 10-year safety follow-up in patients with local VEGF gene transfer to ischemic lower limb. Gene Ther 19: 392-395. [PubMed]

20. Morishita R, Nakamura S, Hayashi S, Taniyama Y, Moriguchi A, et al. (1999) Therapeutic angiogenesis induced by human recombinant hepatocyte growth factor in rabbit hind limb ischemia model as cytokine supplement therapy. Hypertension 33: 1379-1384. [PubMed]

21. Taniyama $\mathrm{Y}$, Morishita R, Aoki M, Nakagami H, Yamamoto K, et al. (2001) Therapeutic angiogenesis induced by human hepatocyte growth factor gene in rat and rabbit hindlimb ischemia models: preclinical study for treatment of peripheral arterial disease. Gene Ther 8: 181-189. [PubMed] 
22. Taniyama $\mathrm{Y}$, Morishita R, Hiraoka K, Aoki M, Nakagami H, et al. (2001) Therapeutic angiogenesis induced by human hepatocyte growth factor gene in rat diabetic hind limb ischemia model: molecular mechanisms of delayed angiogenesis in diabetes. Circulation 104: 2344-2350. [PubMed]

23. Hiraoka K, Koike H, Yamamoto S, Tomita N, Yokoyama C, et al. (2003) Enhanced therapeutic angiogenesis by cotransfection of prostacyclin synthase gene or optimization of intramuscular injection of naked plasmid DNA. Circulation 108: 2689-2696. [PubMed]

24. Koike H, Morishita R, Iguchi S, Aoki M, Matsumoto K, et al. (2003) Enhanced angiogenesis and improvement of neuropathy by cotransfection of human hepatocyte growth factor and prostacyclin synthase gene. FASEB J 17: 779781. [PubMed]

25. Powell RJ, Simons M, Mendelsohn FO, Daniel G, Henry TD, et al. (2008) Results of a double-blind, placebo-controlled study to assess the safety of intramuscular injection of hepatocyte growth factor plasmid to improve limb perfusion in patients with critical limb ischemia. Circulation 118: 58-65. [PubMed]

26. Shigematsu H, Yasuda K, Iwai T, Sasajima T, Ishimaru S, et al. (2010) Randomized, double-blind, placebo-controlled clinical trial of hepatocyte growth factor plasmid for critical limb ischemia. Gene Ther 17: 1152-1161. [PubMed]

27. Beenken A, Mohammadi M (2009) The FGF family: biology, pathophysiology and therapy. Nat Rev Drug Discov 8: 235-253. [PubMed]

28. Comerota AJ, Throm RC, Miller KA, Henry T, Chronos N, et al. (2002) Naked plasmid DNA encoding fibroblast growth factor type 1 for the treatment of end-stage unreconstructible lower extremity ischemia: preliminary results of a phase I trial. J Vasc Surg 35: 930-936. [PubMed]

29. Nikol S, Baumgartner I, Van Belle E, Diehm C, Visona A, et al. (2008) Therapeutic angiogenesis with intramuscular NV1FGF improves amputationfree survival in patients with critical limb ischemia. Mol Ther 16: 972-978. [PubMed]

30. Belch J, Hiatt WR, Baumgartner I, Driver IV, Nikol S, et al. (2011) Effect of fibroblast growth factor NV1FGF on amputation and death: a randomised placebo-controlled trial of gene therapy in critical limb ischaemia. Lancet 377 : 1929-1937. [PubMed]

31. Asahara T, Murohara T, Sullivan A, Silver M, van der Zee R, et al. (1997) Isolation of putative progenitor endothelial cells for angiogenesis. Science 275 964-967. [PubMed]

32. Takahashi T, Kalka C, Masuda H, Chen D, Silver M, et al. (1999) Ischemia- and cytokine-induced mobilization of bone marrow-derived endothelial progenito cells for neovascularization. Nat Med 5: 434-438. [PubMed]

33. Masuda H, Kalka C, Takahashi T, Yoshida M, Wada M, et al. (2007) Estrogenmediated endothelial progenitor cell biology and kinetics for physiological postnatal vasculogenesis. Circ Res 101: 598-606. [PubMed]

34. Orlic D, Kajstura J, Chimenti S, Jakoniuk I, Anderson SM, et al. (2001) Bone marrow cells regenerate infarcted myocardium. Nature 410: 701-705. [PubMed]

35. Narmoneva DA, Vukmirovic R, Davis ME, Kamm RD, Lee RT (2004) Endothelial cells promote cardiac myocyte survival and spatial reorganization: implications for cardiac regeneration. Circulation 110: 962-968. [PubMed]

36. Kamihata H, Matsubara H, Nishiue T, Fujiyama S, Amano K, et al. (2002) Improvement of collateral perfusion and regional function by implantation of peripheral blood mononuclear cells into ischemic hibernating myocardium Arterioscler Thromb Vasc Biol 22: 1804-1810. [PubMed]

37. Kinnaird T, Stabile E, Burnett MS, Lee CW, Barr S, et al. (2004) Marrowderived stromal cells express genes encoding a broad spectrum of arteriogenic cytokines and promote in vitro and in vivo arteriogenesis through paracrine mechanisms. Circ Res 94: 678-685. [PubMed]

38. Kinnaird T, Stabile E, Burnett MS, Shou M, Lee CW, et al. (2004) Loca delivery of marrow-derived stromal cells augments collateral perfusion through paracrine mechanisms. Circulation 109: 1543-1549. [PubMed]

39. Rehman J, Li J, Orschell CM, March KL (2003) Peripheral blood "endothelia progenitor cells" are derived from monocyte/macrophages and secrete angiogenic growth factors. Circulation 107: 1164-1169. [PubMed]

40. Wollert KC, Drexler H (2005) Clinical applications of stem cells for the heart. Circ Res 96: 151-163. [PubMed]

41. Gehling UM, Ergun S, Schumacher U, Wagener C, Pantel K, et al. (2000) In vitro differentiation of endothelial cells from AC133-positive progenitor cells. Blood 95: 3106-3112. [PubMed]

42. Kocher AA, Schuster MD, Szabolcs MJ, Takuma S, Burkhoff D, et al. (2001) Neovascularization of ischemic myocardium by human bone-marrow-derived angioblasts prevents cardiomyocyte apoptosis, reduces remodeling and improves cardiac function. Nat Med 7: 430-436. [PubMed]

43. Kawamoto A, Iwasaki H, Kusano K, Murayama T, Oyamada A, et al. (2006) CD34-positive cells exhibit increased potency and safety for therapeutic neovascularization after myocardial infarction compared with total mononuclear cells. Circulation 114: 2163-2169. [PubMed]

44. Ramos AL, Darabi R, Akbarloo N, Borges L, Catanese J, et al. (2010) Clona analysis reveals a common progenitor for endothelial, myeloid, and lymphoid precursors in umbilical cord blood. Circ Res 107: 1460-1469. [PubMed]

45. Masuda H, Alev C, Akimaru H, Ito R, Shizuno T, et al. (2011) Methodological development of a clonogenic assay to determine endothelial progenitor cell potential. Circ Res 109: 20-37. [PubMed]

46. Tateishi-Yuyama E, Matsubara H, Murohara T, Ikeda U, Shintani S, et al. (2002) Therapeutic angiogenesis for patients with limb ischaemia by autologous transplantation of bone-marrow cells: a pilot study and a randomised controlled trial. Lancet 360: 427-435. [PubMed]

47. Matoba S, Tatsumi T, Murohara T, Imaizumi T, Katsuda Y, et al. (2008) Long-term clinical outcome after intramuscular implantation of bone marrow mononuclear cells (Therapeutic Angiogenesis by Cell Transplantation [TACT] trial) in patients with chronic limb ischemia. Am Heart J 156: 1010-1018.

48. Walter DH, Krankenberg H, Balzer JO, Kalka C, Baumgartner I, et al. (2011) Intraarterial administration of bone marrow mononuclear cells in patients with critical limb ischemia: a randomized-start, placebo-controlled pilot tria (PROVASA). Circ Cardiovasc Interv 4: 26-37. [PubMed]

49. Ishida A, Ohya Y, Sakuda H, Ohshiro K, Higashiuesato Y, et al. (2005) Autologous peripheral blood mononuclear cell implantation for patients with peripheral arterial disease improves limb ischemia. Circ J 69: 1260-1265 [PubMed]

50. Lenk K, Adams V, Lurz P, Erbs S, Linke A, et al. (2005) Therapeutical potentia of blood-derived progenitor cells in patients with peripheral arterial occlusive disease and critical limb ischaemia. Eur Heart J 26: 1903-1909. [PubMed]

51. Huang P, Li S, Han M, Xiao Z, Yang R, et al. (2005) Autologous transplantation of granulocyte colony-stimulating factor-mobilized peripheral blood mononuclear cells improves critical limb ischemia in diabetes. Diabetes Care 28: 2155-2160. [PubMed]

52. Lara-Hernandez $R$, Lozano-Vilardell $P$, Blanes $P$, Torreguitart-Mirada $N$ Galmes A, et al. (2010) Safety and efficacy of therapeutic angiogenesis as a novel treatment in patients with critical limb ischemia. Ann Vasc Surg 24: 287294. [PubMed]

53. Huang PP, Yang XF, Li SZ, Wen JC, Zhang Y, et al. (2007) Randomised comparison of G-CSF-mobilized peripheral blood mononuclear cells versus bone marrow-mononuclear cells for the treatment of patients with lower limb arteriosclerosis obliterans. Thromb Haemost 98: 1335-1342. [PubMed]

54. Tateno K, Minamino T, Toko H, Akazawa H, Shimizu N, et al. (2006) Critical roles of muscle-secreted angiogenic factors in therapeutic neovascularization. Circ Res 98: 1194-1202. [PubMed]

55. Moriya J, Minamino T, Tateno K, Shimizu N, Kuwabara Y, et al. (2009) Long-term outcome of therapeutic neovascularization using peripheral blood mononuclear cells for limb ischemia. Circ Cardiovasc Interv 2: 245-254. [PubMed]

56. Horie T, Onodera R, Akamastu M, Ichikawa Y, Hoshino J, et al. (2010) Long-term clinical outcomes for patients with lower limb ischemia implanted with G-CSF mobilized autologous peripheral blood mononuclear cells. Atherosclerosis 208 : 461-466. [PubMed]

57. Choi JH, Kim KL, Huh W, Kim B, Byun J, et al. (2004) Decreased number and impaired angiogenic function of endothelial progenitor cells in patients with chronic renal failure. Arterioscler Thromb Vasc Biol 24: 1246-1252. [PubMed]

58. Onodera R, Teramukai S, Tanaka S, Kojima S, Horie T, et al. (2011) Bone marrow mononuclear cells versus G-CSF-mobilized peripheral blood mononuclear cells for treatment of lower limb ASO: pooled analysis for longterm prognosis. Bone Marrow Transplant 46: 278-284. [PubMed]

59. Kawamoto A, Katayama M, Handa N, Kinoshita M, Takano H, et al. (2009) 
Intramuscular transplantation of G-CSF-mobilized CD34(+) cells in patients with critical limb ischemia: a phase I/lla, multicenter, single-blinded, doseescalation clinical trial. Stem Cells 27: 2857-2864. [PubMed]

60. Kinoshita M, Fujita Y, Katayama M, Baba R, Shibakawa M, et al. (2012) Longterm clinical outcome after intramuscular transplantation of granulocyte colony stimulating factor-mobilized CD34 positive cells in patients with critical limb ischemia. Atherosclerosis 224: 440-445. [PubMed]

61. Fujita Y, Kinoshita M, Furukawa Y, Nagano T, Hashimoto H, et al. (2014) Phase II clinical trial of CD34+ cell therapy to explore endpoint selection and timing in patients with critical limb ischemia. Circ J 78: 490-501. [PubMed]

62. Losordo DW, Kibbe MR, Mendelsohn F, Marston W, Driver VR, et al. (2012) A randomized, controlled pilot study of autologous CD34+ cell therapy for critical limb ischemia. Circ Cardiovasc Interv 5: 821-830. [PubMed]

63. Burt RK, Testori A, Oyama Y, Rodriguez HE, Yaung K, et al. (2010) Autologous peripheral blood CD133+ cell implantation for limb salvage in patients with critical limb ischemia. Bone Marrow Transplant 45: 111-116. [PubMed]

64. Storms RW, Trujillo AP, Springer JB, Shah L, Colvin OM, et al. (1999) Isolation of primitive human hematopoietic progenitors on the basis of aldehyde dehydrogenase activity. Proc Natl Acad Sci USA 96: 9118-9123. [PubMed]

65. Gentry T, Foster S, Winstead L, DeibertE, Fiordalisi M, et al. (2007) Simultaneous isolation of human BM hematopoietic, endothelial and mesenchymal progenitor cells by flow sorting based on aldehyde dehydrogenase activity: implications for cell therapy. Cytotherapy 9: 259-274. [PubMed]

66. Capoccia BJ, Robson DL, Levac KD, Maxwell DJ, Hohm SA, et al. (2009) Revascularization of ischemic limbs after transplantation of human bone marrow cells with high aldehyde dehydrogenase activity. Blood 113: 53405351. [PubMed]

67. Perin EC, Silva G, Gahremanpour A, Canales J, Zheng Y, et al. (2011) A randomized, controlled study of autologous therapy with bone marrow-derived aldehyde dehydrogenase bright cells in patients with critical limb ischemia. Catheter Cardiovasc Interv 78: 1060-1067. [PubMed]

68. Jiang Y, Jahagirdar BN, Reinhardt RL, Schwartz RE, Keene CD, et al. (2002) Pluripotency of mesenchymal stem cells derived from adult marrow. Nature 418: 41-49. [PubMed]

69. Alhadlaq A, Mao JJ (2004) Mesenchymal stem cells: isolation and therapeutics. Stem Cells Dev 13: 436-448. [PubMed]

70. Chamberlain G, Fox J, Ashton B, Middleton J (2007) Concise review: mesenchymal stem cells: their phenotype, differentiation capacity, immunological features, and potential for homing. Stem Cells 25: 2739-2749. [PubMed]

71. Hare JM, Traverse JH, Henry TD, Dib N, Strumpf RK, et al. (2009) A randomized, double-blind, placebo-controlled, dose-escalation study of intravenous adult human mesenchymal stem cells (prochymal) after acute myocardial infarction. J Am Coll Cardiol 54: 2277-2286. [PubMed]

72. Lee JS, Hong JM, Moon GJ, Lee PH, Ahn YH, et al. (2010) A long-term followup study of intravenous autologous mesenchymal stem cell transplantation in patients with ischemic stroke. Stem Cells 28: 1099-1106. [PubMed]

73. Park KS, Kim YS, Kim JH, Choi B, Kim SH, et al. (2010) Trophic molecules derived from human mesenchymal stem cells enhance survival, function, and angiogenesis of isolated islets after transplantation. Transplantation 89: 509517. [PubMed]

74. Kim SW, Han H, Chae GT, Lee SH, Bo S, et al. (2006) Successful stem cell therapy using umbilical cord blood-derived multipotent stem cells for Buerger's disease and ischemic limb disease animal model. Stem Cells 24: 1620-1626. [PubMed]

75. Dash NR, Dash SN, Routray P, Mohapatra S, Mohapatra PC (2009) Targeting nonhealing ulcers of lower extremity in human through autologous bone marrow-derived mesenchymal stem cells. Rejuvenation Res 12: 359-366. [PubMed]

76. Lasala GP, Silva JA, Minguell JJ (2012) Therapeutic angiogenesis in patients with severe limb ischemia by transplantation of a combination stem cell product. J Thorac Cardiovasc Surg 144: 377-382. [PubMed]

77. Lu D, Chen B, Liang Z, Deng W, Jiang Y, et al. (2011) Comparison of bone marrow mesenchymal stem cells with bone marrow-derived mononuclear cells for treatment of diabetic critical limb ischemia and foot ulcer: a double-blind, randomized, controlled trial. Diabetes Res Clin Pract 92: 26-36. [PubMed]
78. Dennis JE, Esterly K, Awadallah A, Parrish CR, Poynter GM, et al. (2007) Clinical-scale expansion of a mixed population of bone-marrow-derived stem and progenitor cells for potential use in bone-tissue regeneration. Stem Cells 25: 2575-2582. [PubMed]

79. Powell RJ, Comerota AJ, Berceli SA, Guzman R, Henry TD, et al. (2011) Interim analysis results from the RESTORE-CLI, a randomized, double-blind multicenter phase II trial comparing expanded autologous bone marrowderived tissue repair cells and placebo in patients with critical limb ischemia. $J$ Vasc Surg 54: 1032-1041. [PubMed]

80. Murohara T (2009) Autologous adipose tissue as a new source of progenitor cells for therapeutic angiogenesis. J Cardiol 53: 155-163. [PubMed]

81. Zuk PA, Zhu M, Mizuno H, Huang J, Futrell JW, et al. (2001) Multilineage cells from human adipose tissue: implications for cell-based therapies. Tissue Eng 7: 211-228. [PubMed]

82. Miyazaki T, Kitagawa Y, Toriyama K, Kobori M, Torii S (2005) Isolation of two human fibroblastic cell populations with multiple but distinct potentia of mesenchymal differentiation by ceiling culture of mature fat cells from subcutaneous adipose tissue. Differentiation 73: 69-78. [PubMed]

83. Sumi M, Sata M, Toya N, Yanaga K, Ohki T, et al. (2007) Transplantation of adipose stromal cells, but not mature adipocytes, augments ischemia-induced angiogenesis. Life Sci 80: 559-565. [PubMed]

84. Kondo K, Shintani S, Shibata R, Murakami H, Murakami R, et al. (2009) Implantation of adipose-derived regenerative cells enhances ischemia-induced angiogenesis. Arterioscler Thromb Vasc Biol 29: 61-66. [PubMed]

85. Traktuev DO, Merfeld-Clauss S, Li J, Kolonin M, Arap W, et al. (2008) A population of multipotent CD34-positive adipose stromal cells share pericyte and mesenchymal surface markers, reside in a periendothelial location, and stabilize endothelial networks. Circ Res 102: 77-85.

86. Rehman J, Traktuev D, Li J, Merfeld-Clauss S, Temm-Grove CJ, et al. (2004) Secretion of angiogenic and antiapoptotic factors by human adipose stromal cells. Circulation 109: 1292-1298. [PubMed]

87. Nakagami H, Maeda K, Morishita R, Iguchi S, Nishikawa T, et al. (2005) Novel autologous cell therapy in ischemic limb disease through growth factor secretion by cultured adipose tissue-derived stromal cells. Arterioscler Thromb Vasc Biol 25: 2542-2547. [PubMed]

88. Bura A, Planat-Benard V, Bourin P, Silvestre JS, Gross F, et al. (2014) Phase trial: the use of autologous cultured adipose-derived stroma/stem cells to treat patients with non-revascularizable critical limb ischemia. Cytotherapy 16: 245257. [PubMed]

89. Teraa M, Sprengers RW, van der Graaf Y, Peters CE, Moll FL, et al. (2013) Autologous bone marrow-derived cell therapy in patients with critical limb ischemia: a meta-analysis of randomized controlled clinical trials. Ann Surg 258: 922-929. [PubMed]

90. Labs KH, Dormandy JA, Jaeger KA, Stuerzebecher CS, Hiatt WR (1999) Transatlantic Conference on Clinical Trial Guidelines in Peripheral Arterial Disease: clinical trial methodology. Basel PAD Clinical Trial Methodology Group. Circulation 100: e75-81. [PubMed]

91. Diehm N, Pattynama PM, Jaff MR, Cremonesi A, Becker GJ, et al. (2008) Clinical endpoints in peripheral endovascular revascularization trials: a case for standardized definitions. Eur J Vasc Endovasc Surg 36: 409-419. [PubMed]

92. Conte MS (2010) Understanding objective performance goals for critical limb ischemia trials. Semin Vasc Surg 23: 129-137. [PubMed]

93. Higashi Y, Kimura M, Hara K, Noma K, Jitsuiki D, et al. (2004) Autologous bone-marrow mononuclear cell implantation improves endothelium-dependent vasodilation in patients with limb ischemia. Circulation 109: 1215-1218. [PubMed]

94. Miyamoto K, Nishigami K, Nagaya N, Akutsu K, Chiku M, et al. (2006) Unblinded pilot study of autologous transplantation of bone marrow mononuclear cells in patients with thromboangiitis obliterans. Circulation 114: 2679-2684. [PubMed]

95. Motukuru V, Suresh KR, Vivekanand V, Raj S, Girija KR (2008) Therapeutic angiogenesis in Buerger's disease (thromboangiitis obliterans) patients with critical limb ischemia by autologous transplantation of bone marrow mononuclear cells. J Vasc Surg 48: 53S-60S. [PubMed]

96. De Vriese AS, Billiet J, Van Droogenbroeck J, Ghekiere J, De Letter JA (2008) Autologous transplantation of bone marrow mononuclear cells for limb ischemia in a caucasian population with atherosclerosis obliterans. J Intern Med 263 395-403. [PubMed] 
Citation: Fujita Y, Kawamoto A (2014) Cell-Based Therapies for Peripheral Arterial Disease. J Stem Cell Res Ther 4: 234. doi:10.4172/21577633.1000234

97. Cobellis G, Silvestroni A, Lillo S, Sica G, Botti C, et al. (2008) Long-term effects of repeated autologous transplantation of bone marrow cells in patients affected by peripheral arterial disease. Bone Marrow Transplant 42: 667-672. [PubMed]

98. Chochola M, Pytlik R, Kobylka P, Skalicka L, Kideryova L, et al. (2008) Autologous intra-arterial infusion of bone marrow mononuclear cells in patients with critical leg ischemia. Int Angiol 27: 281-290. [PubMed]

99. Franz RW, Parks A, Shah KJ, Hankins T, Hartman JF, et al. (2009) Use of autologous bone marrow mononuclear cell implantation therapy as a limb salvage procedure in patients with severe peripheral arterial disease. J Vasc Surg 50: 1378-1390. [PubMed]

100. Amann B, Luedemann C, Ratei R, Schmidt-Lucke JA (2009) Autologous bone marrow cell transplantation increases leg perfusion and reduces amputations in patients with advanced critical limb ischemia due to peripheral artery disease. Cell Transplant 18: 371-380. [PubMed]

101. Prochazka V, Gumulec J, Jaluvka F, Salounova D, Jonszta T, et al. (2010) Cell therapy, a new standard in management of chronic critical limb ischemia and foot ulcer. Cell Transplant 19: 1413-1424. [PubMed]

102. Ruiz-Salmeron R, de la Cuesta-Diaz A, Constantino-Bermejo M, PerezCamacho I, Marcos-Sanchez F, et al. (2011) Angiographic demonstration of neoangiogenesis after intra-arterial infusion of autologous bone marrow mononuclear cells in diabetic patients with critical limb ischemia. Cell Transplant 20: 1629-1639. [PubMed]
103. Murphy MP, Lawson JH, Rapp BM, Dalsing MC, Klein J, et al. (2011) Autologous bone marrow mononuclear cell therapy is safe and promotes amputation-free survival in patients with critical limb ischemia. J Vasc Surg 53: 1565-1574. [PubMed]

104. Idei N, Soga J, Hata T, Fujii Y, Fujimura N, et al. (2011) Autologous bonemarrow mononuclear cell implantation reduces long-term major amputation risk in patients with critical limb ischemia: a comparison of atherosclerotic peripheral arterial disease and Buerger disease. Circ Cardiovasc Interv 4: 1525. [PubMed]

105. Benoit E, O'Donnell TF Jr, lafrati MD, Asher E, Bandyk DF, et al. (2011) The role of amputation as an outcome measure in cellular therapy for critical limb ischemia: implications for clinical trial design. J Transl Med 9: 165. [PubMed]

106. Klepanec A, Mistrik M, Altaner C, Valachovicova M, Olejarova I, et al. (2012) No Difference in Intraarterial and Intramuscular Delivery of Autologous Bone-Marrow Cells in Patients with Advanced Critical Limb Ischemia. Cell Transplantation 21: 1909-1918. [PubMed]

107. Huang PP, Li SZ, Han MZ, Xiao ZJ, Yang RC, et al (2004) Autologous transplantation of peripheral blood stem cells as an effective therapeutic approach for severe arteriosclerosis obliterans of lower extremities. Thromb Haemost 91: 606-609. [PubMed]

108. Lasala GP, Silva JA, Gardner PA, Minguell JJ (2010) Combination stem cell therapy for the treatment of severe limb ischemia: safety and efficacy analysis. Angiology 61: 551-556. [PubMed] 